Volume 4 Nomor 2 Oktober 2020

e-ISSN: 2549-9114 dan p-ISSN: 2549-9203

(Received: Maret-2020; Reviewed: Juli -2020; Published: Oktober-2020)

https://doi.org/10.26858/pembelajar.v4i2.13006

\title{
Efektivitas Penerapan Metode Hypnoteaching Dalam Meningkatkan Aktivitas Belajar Siswa
}

\author{
Ida Bagus Alit Arta Wiguna \\ aAHN Gde Pudja Mataram
}

Corresponding e-mail: gusarta.iahn@gmail.com

\begin{abstract}
Abstrak: Guru dituntut memiliki kemampuan secara metodelogis dalam perancangan dan pelaksanaan pembelajaran. Penerapan metode Hypnoteaching dalam meningkatkan aktivitas belajar sangat membantu proses pembelajaran didalam kelas dan meningkatkan motivasi belajar yang berdampak pada peningkatan aktivitas belajar. Penelitian ini menggunakan metode penelitian kombinasi model sequential exploratory metode penelitian kombinasi yang menggabungkan penelitian kualitatif dan kuantitatif secara berurutan dimana pada tahap pertama penelitian menggunakan metode kualitatif dan pada tahap ke dua metode kuantitatif. Metode kualitatif berfungsi untuk mendukung hipotesis pada kasus tertentu atau sampel terbatas dan metode kuantitatif berfungsi untuk mendukung hipotesis pada populasi lebih luas. Penerapan metode Hypnoteaching yang diberikan oleh guru di kelas X sangat efektif menjadikan suasana kelas yang pasif menjadi tenang dan aktif apabila diberikan stimulus metode Hypnoteaching. Suasana pembelajaran di kelas yang menyenangkan akan menyebabkan siswa menjadi betah saat belajar di dalam kelas. Dari hasil perhitungan nilai rata-rata dan daya serap siswa diatas diperoleh hasil untuk rata-rata dari keseluruhan hasil belajar siswa di kelas X Mipa 6 adalah 88 dan daya serap diperoleh dari skor rata-rata siswa adalah $88 \%$. Hasil tersebut menunjukan bahwa rata-rata skor atau nilai siswa berada pada rentang 61-100 dengan kategori Efektif dan Sangat Efektif.
\end{abstract}

Kata Kunci : Efektivitas, Metode Hypnoteaching, Aktivitas belajar

Abstract: Teachers are required to have methodological abilities in the design and implementation of learning. The application of Hypnoteaching method in increasing learning activities greatly helps the learning process in the classroom and increases learning motivation which has an impact on increasing learning activities. This research uses a combination of sequential exploratory research methods. Combined research methods that combine qualitative and quantitative research sequentially where in the first phase of research using qualitative methods and in the second stage quantitative methods. Qualitative methods function to support hypotheses in certain cases or limited samples and quantitative methods function to support hypotheses in a wider population. The application of the Hypnoteaching method given by the teacher in class $\mathrm{X}$ is very effective in making the passive classroom atmosphere become calm and active when given a Hypnoteaching method stimulus. The fun atmosphere of learning in the classroom will cause students to feel at home while learning in class. From the results of the calculation of the average value and absorption of the above students obtained results for the average of the overall learning outcomes of students in class X Mipa 6 is 88 and the absorbency obtained from the average score of students is $88 \%$. These results indicate that the average score or value of students is in the range of 61-100 with the category of Effective and Very Effective.

Keywords: Effectiveness, Hypnoteaching Method, Learning Activities 
Ida Bagus Alit Arta Wiguna. Efektivitas Penerapan Metode Hypnoteaching Dalam Meningkatkan Aktivitas Belajar Siswa

\section{PENDAHULUAN}

Transfer pengetahuan merupakan sebuah konsep untuk berbagi informasi dalam proses pembelajaran baik di pendididkan formal maupun pendididkan informal. Dalam interaksi dalam pendidikan formal keprofesionalan seorang guru sedang dituntut dan diberikan tunjangan oleh pemerintah. Berbicara terkait keprofesionalan guru hendaknya guru harus terus memperbaharui ilmu yang dimilikinya baik dengan mengembangkan jabatan akademik maupun melalui tes uji kompetensi guru.

Guru dituntut profesional dalam menjalankan tugas di sekolah. Terutama dalam tuntutan melaksanakan pembelajaran didalam kelas. Guru harus memiliki strategi pembelajaran seperti media dan metode dalam melaksanakan proses pembelajaran. Metode pembelajaran merupakan salah satu unsur penting dalam mentransfer materi kepada siswa. Metode pembelajaran yang tepat dan benar akan berpengaruh terhadap kualitas penyerapan materi siswa, sehingga kedalaman materi dapat dengan mudah dipahami oleh siswa. Jika para guru mampu menerapkan sebuah metode pembelajaran dengan baik dan benar, maka besar kemungkinan hasil belajar siswa dapat memberi kepuasan baik kepada dirinya, guru maupun orang tua. (Karim, 2017)

Apabila guru hanya menggunakan metode pembelajaran yang monoton maka dipastikan suasana dalam kelas akan terasa membosankan. Banyak terjadi dilapangan bahwa guru sedikit yang mau merubah kebiasaanya mengajar yang masih menggunakan metode konvensional seperti metode ceramah. Guru dituntut sebagai seorang profesional dalam bidangnya hendaknya harus memiliki inovasi terhadap perkembangan ilmu pengetahuan yang begitu pesat. (Arta Wiguna, 2017)

Salah satu tolok ukur berhasilnya proses transfer pengetahuan adalah dengan berhasilnya siswa memiliki pemahaman tentang materi yang diajarkan oleh guru. Tinggi rendahnya hasil yang diperoleh siswa tergantung dalam kemampuan guru menyampaikan materi dikelas.

Guru merupakan tenaga profesional yang bertugas merencanakan dan melaksanakan proses pembelajaran. Pendidik professional berarti memiliki kompetensi - kompetensi yang dibutuhkan untuk mampu mendidik secara professional antara lain adalah : (1) mengenal siswa secara mendalam; (2) menguasai bidang studi; (3) menyelenggarakan pembelajaran yang mendidik; (4) meningkatkan profesionalitas secara berkelanjutan; dan (5) meningkatkan profesionalitas pelaksanaan tugas sebagai pendidik ( kepribadian, pembelajaran, dan komunikasi ). Guru sebagai pendidik professional diidealkan mampu menjadi agen pembelajaran yang edukatif, yaitu dapat menjadi fasilitator, motivator, pemacu, perekayasa, dan inspirator pembelajaran. (Sudarsana, 2017)

Untuk mencapai proses belajar mengajar yang efektif, guru dituntut memiliki kemampuan secara metodelogis dalam hal perancangan dan pelaksanaan pembelajaran. Penerapan metode Hypnoteaching dalam meningkatkan aktivitas belajar sangat membantu proses pembelajaran didalam kelas, karena siswa dapat meningkatkan motivasi belajar yang berdampak pada peningkatan aktivitas belajar siswa dan guru di tuntut harus memiliki kreaktivitas gaya mengajar agar tidak monoton disinilah peranan bagi seorang guru yang harus menerapkan strategi strategi pembelajaran.

Hypnoteaching merupakan sebuah model pembelajaran yang dapat diterapkan karena model ini sangat mudah beradaptasi dengan kondisi siswa. Sebagaimana dikemukakan secara harfiah, Hypnoteaching berasal dari kata hypnosis dan teaching. Hypnosis sendiri adalah seni berkomunikasi untuk mempengaruhi seseorang, sehingga mengubah tingkat kesadarannya, yang dicapai dengan cara menurunkan gelombang otak dari betha menjadi alpha atau theta. Sedangkan teaching adalah mengajar. dari sini, kemudian bisa diartikan bahwa Hypnoteaching adalah seni berkomunikasi dalam mengajar dengan jalan memberikan sugesti agar para siswa menjadi lebih cerdas. Melalui sugesti yang diberikan, diharapkan mereka tersadar dan tercerahkan bahwa ada potensi luar biasa yang selama ini belum pernah mereka optimalkan dalam pembelajaran. (Kihlstrom, 2016)

Hypnoteaching merupakan perpaduan pengajaran yang melibatkan pikiran sadar dan bawah sadar. Hypnoteaching ini merupakan 
metode pembelajaran kreatif, unik, sekaligus imajinatif. Sebelum pelaksanaan pembelajaran, para anak didik sudah dikondisikan untuk siap belajar. Dengan demikian, anak didik mengikuti pembelajaran dalam kondisi yang segar dan siap untuk menerima materi pelajaran. Untuk mempersiapkan hal-hal tersebut, tentu guru dituntut stabil baik secara psikologis, maupun secara psikis, akhirnya mempunyai kesiapan yang penuh dalam mengajar para anak didiknya. (Yustisia, 2016)

Pelaksanaan proses belajar mengajar dengan menggunakan metode Hypnoteaching siswa cenderung lebih aktif dan lebih sering merespon pertanyaan yang diberikan oleh guru disetiap proses pembelajaran berlangsung. Respon yang dimaksud adalah pertanyaan, jawaban ataupun argumentasi yang diberikan oleh siswa dalam pembelajaran. Menyimak kenyataan seperti ini, perlu adanya sebuah usaha untuk meningkatkan kemampuan siswa dan merangsang perilaku siswa dalam proses belajar. Salah satu usaha yang dapat digunakan untuk meningkatkan aktivitas siswa dalam peningkatan rasa percaya diri menjawab pertanyaan, beragumentasi, adalah melalui metode Hypnoteaching.

Penerapan metode Hypnoteaching maka akan merangsang siswa untuk melatih dan mengembangkan daya pikir serta membangkitkan keberhasilan siswa dan keterampilan belajar mengajar, metode Hypnoteaching yang diterapkan dapat berupa ketenangan pikiran pada saat proses belajar mengajar, Arahan - Arahan yang disiapkan oleh guru maupun siswa yang menyangkut tentang materi pelajaran dan siswa menjawab pertanyaan yang di berikan oleh guru pada saat pembelajaran berlangsung. Dari latar belakang permasalahan di atas peneliti ingin meneliti hal sebagai berikut.

\section{METODE}

Penelitian ini menggunakan metode penelitian kombinasi model model sequential exploratory yang karakteristik penelitiannya terletak pada fokus penelitian. Metode penelitian kombinasi model sequential exploratory adalah metode penelitian kombinasi yang menggabungkan metode penelitian kualitatif dan kuantitatif secara berurutan dimana pada tahap pertama penelitian menggunakan metode kualitatif dan pada tahap ke dua metode kuantitatif. Metode kualitatif berfungsi untuk mendukung hipotesis pada kasus tertentu atau sampel terbatas dan metode kuantitatif kuantitatif berfungsi untuk mendukung hipotesis pada populasi lebih luas. Jadi metode ini berguna untuk menemukan hipotesis dan sekaligus membuktikan validitas eksternal hipotesis (Sugiyono, 2012)

Penelitian ini menggambil objek di kelas $\mathrm{X}$ karena jumlah siswa yang paling aktif dibandingkan dengan kelas XI, XII yang cenderung lebih pasif dalam kegiatan belajar mengajar. Kelas $\mathrm{X}$ sangat aktif dalam pembelajaran berkelanjutan. Hal-hal yang diamati melibatkan siswa, guru, situasi dan kondisi kelas dalam pembelajaran.. semua siswa kelas X SMAN 7 Denpasar berjumlah 389 siswa dibagi menjadi 12 kelas. Dengan melihat keefektifan siswa menangkap pelajaran dengan metode Hypnoteaching yang diberikan oleh guru dengan menggambil sampel satu kelas yaitu kelas $X$ Mipa 6 dengan jumlah 34 siswa.

Pengumpulan data untuk melihat penerapan metode Hypnoteaching dalam meningkatkan aktivitas belajar siswa menggunakan skor rata rata $(\mathrm{Me})$ yang dihitung dengan rumus :

1. Menghitung rata-rata nilai siswa kelas $X$ SMAN 7 Denpasar dengan rumus :

$\mathbf{M e}=\frac{\sum \mathbf{X}}{\mathbf{N}}$

(Sugiyono, 2014)

Keterangan :

$\mathrm{Me}=$ Mean (rata-rata)

$\sum=$ Epilison (jumlah)

$\mathrm{X}=$ Nilai Siswa

$\mathrm{N}=$ Jumlah Siswa

Dengan demikian nilai siswa maksimun adalah 100 dan minimumnya adalah 0 . Selanjutnya nilai siswa dalam pembelajaran dikatagorikan dalam skala linkert lima yaitu sangat efektif, efektif, cukup efektif, kurang efektif dan tidak efektif.

Berdasarkan hasil perhitungan diatas untuk masing-masing katagori ini, dapat disusun pedoman konversi penerapan metode Hypnoteaching dalam meningkatkan aktifitas belajar siswa kelas X SMAN 7 Denpasar seperti tabel berikut :

Tabel : 2.1 Konversi penerapan metode Hypnoteaching dalam mengaitkan aktivitas siswa

\begin{tabular}{ccl} 
No & Nilai Siswa & \multicolumn{1}{c}{ Kategori } \\
\hline 1 & $86-100$ & Sangat efektif \\
2 & $66-85$ & Efektif \\
3 & $46-65$ & Cukup efektif \\
4 & $26-45$ & Kurang efektif \\
5 & $0-25$ & Tidak efektif \\
\hline
\end{tabular}

2. Disamping itu akan dilihat juga daya serap siswa. dengan rumus daya serap sebagai berikut : (Sugiyono, 2014)

$$
\text { DS }=\text { Me. } 10 \%
$$


Ida Bagus Alit Arta Wiguna. Efektivitas Penerapan Metode Hypnoteaching Dalam Meningkatkan

Aktivitas Belajar Siswa

Keterangan :

DS = Daya Serap

$\mathrm{Me}=\mathrm{Rata}-$ rata skor prestasi belajar siswa.

Dalam penelitian ini peneliti menentukan informan. Kriteria orang yang akan dijadikan informan ditentukan terlebih dahulu, selanjutnya orang pertama yang dipakai unit informan terlebih dahulu, selanjutnya orang pertama yang dipakai unit informan ditentukan. Yang menjadi sumber informasi tentang orang lain yang layak dijadikan informan. Adapun data yang diperoleh langsung dari sumber pertama baik individu atau perseoragan seperti hasil wawancara dengan kepala sekolah, wali kelas, guru dan pegawai tata usaha di SMAN 7 Denpasar.

Penentuan informan dalam penelitian ini ditentukan dengan cara Purposive Sampling. Informan kunci dalam penelitian ini adalah guru wali kelas di SMAN 7 Denpasar. Informan kunci tersebut peneliti pilih karena guru yang tahu dan mengerti tentang penerapan metode Hypnoteaching di kelas X SMAN 7 Denpasar.

\section{HASIL DAN PEMBAHASAN}

\subsection{Penerapan metode Hypnoteaching}

Pembelajaran efektif bukan membuat siswa pusing, akan tetapi bagaimana tujuan pembelajaran dapat tercapai dengan mudah dan menyenangkan. Motivasi berpangkal dari kata motif yang dapat diartikan sebagai daya penggerak yang ada di dalam diri seseorang untuk melakukan aktivitas-aktivitas tertentu demi tercapainya suatu tujuan. Bahkan motif dapat diartikan sebagai suatu kondisi intern (kesiapsiagaan). Dalam kegiatan belajar, motivasi sangat diperlukan, sebab seseorang yang tidak mempunyai motivasi dalam belajar, tidak akan mungkin melakukan aktivitas belajar. Bagi siswa yang selalu memperhatikan materi pelajaran yang diberikan, bukanlah masalah bagi guru. karena didalam diri siswa tersebut ada motivasi. Siswa yang demikian biasanya dengan kesadaran sendiri memperhatikan penjelasan guru. Rasa ingin tahunya lebih banyak terhadap materi pelajaran yang diberikan. berbagai gangguan yang ada disekitarnya tidak berpengaruh besar untukm memecahkan perhatiannya. Lain halnya bagi siswa yang tidak ada motivasi didalam dirinya, maka motivasi yang merupakan dorongan dari luar dirinya mutlak diperlukan untuk meningkatkan aktivitas belajar.

Hypnoteaching merupakan perpaduan dari konsep aktivitas belajar mengajar dengan ilmu hipnosis. Belajar akan terasa lebih menyenangkan, damai, tenang, rileks, dan enjoy andaisaja para guru dan pendidik dapat mengaplikasikan konsep pendekatan hipnosis yang kaya akan makna sugestif dalam dunia pendidikan dan pengajaran di kelas, tanpa harus mengurangi hakikat dari tujuan kurikulum. Hypnoteaching hanya bermain pada tataran "proses pembelajaran" saja, bukan pada masalah filosofi pendidikan. Menikmati kedamaian, kesejukan, rileksasi, dan ketenangan dalam kegiatan belajar mengajar melalui pendekatan Hypnoteaching.

\subsubsection{Penerapan metode Hypnoteaching oleh guru dalam proses pembelajaran}

Hypnoteaching menekankan pada komunikasi alam bawah sadar siswa, baik yang dilakukan dalam kelas maupun luar kelas. Hal ini bisa dilakukan dengan berbagai cara, seperti sugesti dan imajinasi. Sugesti memiliki kekuatan luar biasa. Kemampuan sugesti yang terus terngiang dalam otak, mampu mengantarkan seseorang pada apa yang dipikirkan. Sedangkan imajinasi merupakan proses membayangkan sesuatu terlebih dahulu, baru melakukannya. Dalam hal ini seorang guru harus mampu membiarkan siswa berekspresi dan berimajinasi.

Langkah dalam penerapan metode Hypnoteaching oleh guru perlu memperhatikan sebagai berikut:

a. Niat dan Motivasi Guru sebelum mengajar.

Kesuksesan seseorang tergantung pada niat dalam dirinya untuk bersusah payah dan bekerja keras dalam mencapai kesuksesan tersebut. Niat yang dimaksud adalah kemauan keras pada diri guru untuk memberikan pelajaran yang berkualitas dan mampu memperbaiki kualitas belajar siswa. Niat guru sebelum mengajar dapat dilihat dari kesungguhannya dalam mempersiapkan dan menguasai metode pembelajaran ataupun materi pembelajaran.

b. Pacing.

Pacing berarti menyamakan posisi, gerak tubuh, bahasa, serta gelombang otak siswa dengan menggunakan alat EEG (electro encephalo graph) gelombang pikiran terbagi menjadi empat kategori yaitu gelombang otak Beta, gelombang otak Alfa, gelombang otak Theta, dan gelombang otak Delta. Gelombang otak Beta adalah kondisi saat seseorang sadar sepenuhnya yaitu ketika seseorang beraktivitas dengan fokus lebih dari satu hal. Gelombang otak Alfa adalah kondisi seseorang benar-benar dalam kondisi relaks dan fokus. Kondisi inilah yang dimaksud dengan kondisi hypnosis, yaitu saat 
seseorang mudah menyerap informasi secara maksimal tanpa adanya pikiran-pikiran lain yang mengganggu. Gelombang otak Theta adalah kondisi seseorang berada dalam kondisi setengah tertidur atau disebut kondisi meditatif. Gelombang otak Delta adalah kondisi seseorang dalam keadaan tidur pulas atau bisa dikatakan telah memasuki kondisi tidak sadarkan diri. Pacing bertujuan membangun kedekatan guru dengan siswa. (Hasbullah \& Rahmawati, 2015) c. Leading.

Leading berarti memimpin atau mengarahkan setelah proses pacing di lakukan. Setelah melakukan pacing, para siswa akan merasa nyaman dengan guru. Pada saat itulah hampir setiap apapun yang guru ucapkan atau tugaskan kepada mereka, akan dilakukan dengan suka rela dan bahagia. Sehingga sesulit apapun materinya, pikiran bawah sadar mereka akan menangkap materi pelajaran dengan mudah. Pada tahapan ini guru dapat memimpin siswa untuk fokus pada materi yang akan dipelajari. Selain itu guru bisa memimpin siswa untuk mengikuti pembelajaran dengan suasana yang nyaman dan menyenangkan.

d. Menggunakan kata - kata positif saat mengajar.

Langkah berikutnya adalah langkah pendukung dalam melakukan pacing dan leading. Penggunaan kata positif ini sesuai dengan cara kerja pikiran bawah sadar yang tidak mau menerima kata negatif.

e. Memberikan pujian kepada siswa.

Pujian merupakan reward peningkatan harga diri seseorang. Pujian merupakan salah satu cara untuk membentuk konsep diri seseorang. Pemberian pujian bisa dilakukan ketika siswa berhasil melakukan atau mencapai prestasi. Berikan pujian sekecil apapun bentuk prestasinya, termasuk ketika ia berhasil melakukan perubahan positif pada dirinya.

f. Modeling.

Modeling adalah proses memberi tauladan melalui ucapan dan perilaku yang konsisten. Hal ini sangat perlu dan menjadi kunci metode Hypnoteaching. Setelah siswa merasa nyaman dengan guru maka diperlukam kepercayaan (trust) siswa kepada guru dengan perilaku guru yang konsisten melalui ucapan dan ajaran guru. Guru harus menjadi figur yang dipercaya

penerapan metode Hypnoteaching juga biasa dilakukan oleh guru sebelum melaksanakan ulangan harian yang bertujuan untuk mengingat kembali materi - materi yang sudah diberikan dengan menjelaskan inti pembelajaran dan selanjutnya melakukan tanya jawab kepada siswa, dengan begitu di harapkan siswa lebih matang mengikuti ulangan harian dan mampu menjawab pertanyaan - pertanyaan dengan tepat. penerapan metode Hypnoteaching untuk meningkatkan daya ingat siswa terhadap materi yang telah diberikan oleh guru. Metode Hypnoteaching cocok digunakan untuk membangkitkan semangat belajar siswa agar siswa tidak merasa bosan dengan pengajaran yang cara penyampaiannya hanya menggunakan metode ceramah dan monoton, metode Hypnoteaching ini juga diharapkan mampu memancing ingatan siswa terhadap materi yang diajarkan sebelumnya agar lebih diingat lagi.

\subsubsection{Penerapan metode Hypnoteaching di kelas X SMA Negeri 7 Denpasar}

Dalam metode Hypnoteaching, guru berperan sebagai hipnotis, sedangkan siswa sebagai suyet. Suyet adalah sebutan orang yang dihipnosis. Guru selaku hipnotis tidak perlu menidurkan siswanya saat memberikan sugesti di dalam proses pembelajaran. mengerti bahasa yang digunakan hipnotis. Saat baru memasuki kelas, guru disarankan tidak langsung memberi salam pembuka atau memberikan pelajaran saat para siswa belum siap belajar dan kelas belum kondusif. Guru cukup duduk manis di kursi tanpa harus menegur, menasihati, ataupun marahmarah. Setelah itu, guru cukup menatap satu persatu siswa yang masih gaduh dengan menggunakan kekuatan psikologis dalam dirinya. Tarik napas dalam-dalam, tahan sebentar di dada, dan lepaskan secara perlahan. Kemudian perhatikan reaksi para siswa. Ulangi kegiatan itu berulang kali hingga pikiran, hati, dan perasaan benar-benar tenang, damai, dan nyaman. Setelah itu, guru akan semakin santai, rileks, dan terlihat lebih penyabar dari sebelumnya. Saat itulah para siswa akan berhenti gaduh serta kelas menjadi lebih kondusif dan terkendali. Siswa yang sudah duduk tenang dan siap menerima pelajaran dengan sendirinya akan menegur dan memperingatkan temannya yang masih ramai, mengantuk, atau tiduran. Tanpa harus emosi, guru mengarahkan perhatian dan konsentrasi siswa pada satu titik fokus, yakni pada bahasa komunikasi sugestinya.

Pelaksanaan Hypnoteaching tidak cukup hanya dilakukan satu atau dua kali saja, tetapi harus dilakukan berulang-ulang dengan terus mengulangi kalimat-kalimat sugesti. Dalam hal ini, kemahiran guru dalam menggunakan metode Hypnoteaching akan sangat tergantung pada sejauh mana guru itu menggunakan, mengamalkan, menerapkan, dan mempraktikkan ilmu ini dalam proses pembelajaran. Metode pembelajaran ini lebih banyak menekankan pada kemampuan otak bawah sadar daripada otak 
sadar siswa. Tujuan metode pembelajaran ini sebenarnya membuka atau mengaktifkan pikiran bawah sadar. Hal ini dilakukan karena pikiran bawah sadar merupakan letak keberhasilan atau kegagalan seseorang. Pikiran bawah sadar memegang peranan $88 \%$, sedangkan pikiran sadar hanya berperan $12 \%$ saja.

Penerapan metode Hypnoteaching di kelas X SMA Negeri 7 Denpasar melalui beberapa tahap di bawah ini.

1. Yelling.

Yelling atau berteriak dipakai untuk mengembalikan kosentrasi siswa ke materi pelajaran dengan meneriakan kata "Sisma" di jawab dengan kata "Jaya, jaya, jaya" bersamasama. Ketika konsentrasi siswa mulai terpecah, guru bisa menggunakan teknik ini untuk mengembalikan konsentrasi siswanya.

2. Jam emosi.

Jam emosi merupakan jam mengatur emosi. Pada hakikatnya, emosi setiap orang bisa berubah-ubah setiap detiknya, demikian halnya dengan siswa. Mereka pun memiliki waktu emosi yang berbeda-beda pula. Oleh karena itu di butuhkan suatu cara supaya mereka tetap dalam emosi yang sama pada suatu waktu. Jam emosi di SMA Negeri 7 Denpasar dibagi menjadi empat bagian terdiri sebagai berikut.

a. Jam Tenang

Ditandai dengan tulisan "tenang". Jam ini siswa diminta untuk tenang dan berkonsentrasi karena ada materi penting yang akan disampaikan oleh guru.

b. Jam diskusi

Ditandai dengan tulisan "diskusi". Jam diskusi ini menunjukan bahwa pada waktu tersebut siswa diminta untuk mendiskusikan suatu topik yang barusaja dibahas,

c. Jam lepas

Ditandai dengan tulisan "lepas" jam ini menunjukan siswa diminta untuk melepaskan emosinya. Siswa dapat tertawa, berbicara sebentar dengan teman, atau menghela napas dengan batas waktu tertentu. Hal yang perlu diperhatikan guru adalah bisa mengontrol perilaku siswa pada jam lepas agar tidak mengganggu kelas lain.

d. Jam tombol

Dapat ditandai dengan tulisan "tombol" jam ini menunjukan para siswa mengaktifkan kondisi aktif belajarnya.

3. Ajarkan dan puji

Dalam skala rata-rata, proses pembelajaran menunjukkan bahwa anak mengingat $20 \%$ dari apa yang mereka baca. Anak mengingat 40\% dari apa yang mereka lihat. Anak mengingat $50 \%$ dari apa yang mereka katakan. Anak mengingat $50 \%$ dari apa yang mereka lakukan. Anak mengingat $90 \%$ dari apa yang mereka lihat, dengar, dan katakan.

Melihat sekala belajar di atas, perlu bagi guru untuk melakukan suatu cara yang membuat siswa dapat mencapai presentase $90 \%$ dalam proses pembelajaran. Cara tersebut adalah dengan membuat siswa dapat melihat, mendengar, mengatakan, dan melakukan. Sebab, dengan saling mengajarkan kembali materi kepada teman yang lain, siswa akan dapat memahami materi pembelajaranyang mereka terima sebelumnya.

Setelah itu, ketika siswa telah berusaha untuk saling mengajarkan kepada temannya yang lain, guru harus memberikan apresiasi kepada siswa dengan memujinya.

\section{Pertanyaan ajaib}

Dalam membentuk sebuah pertanyaan yang bisa meningkatkan prestasi belajar siswa, diperlukan suatu pertanyaan khusus yang bisa membangun proses pembelajaran, memberikan solusi, meningkatkan potensi, dan mengarahkan siswa. Usaha tersebut dilakukan untuk membuat siswa menjadi lebih termotivasi dalam mengikuti pembelajaran. Petanyaan yang diajukan oleh guru disebut sebagai pertanyaan ajaib. Pertanyaan ajaib akan membuat siswa menjadi lebih bersemangat dan termotivasi untuk menjawab pertanyaan-pertanyaan ajaib yang diajukan oleh guru.

\subsubsection{Sistem Penerapan metode Hypnoteaching di kelas}

Pada saat kegiatan awal pembelajaran, kesiapan guru dalam membuka pelajaran sudah baik dan perhatian siswa terpusat dengan baik. Ketika pembelajaran dimulai tidak ada lagi siswa yang mengobrol ataupun bercanda. Guru mencurahkan perhatiannya kepada siswa sehingga pembelajaran benar - benar sudah siap untuk dimulai. Kemudian pada saat kegiatan inti, guru menyampaikan materi dengan baik. Suara yang jelas dan kecekatan guru menyampaikan materi pelajaran membuat siswa antusias mengikuti pelajaran. Berikut adalah gambar situasi pada saat guru mulai menggunakan

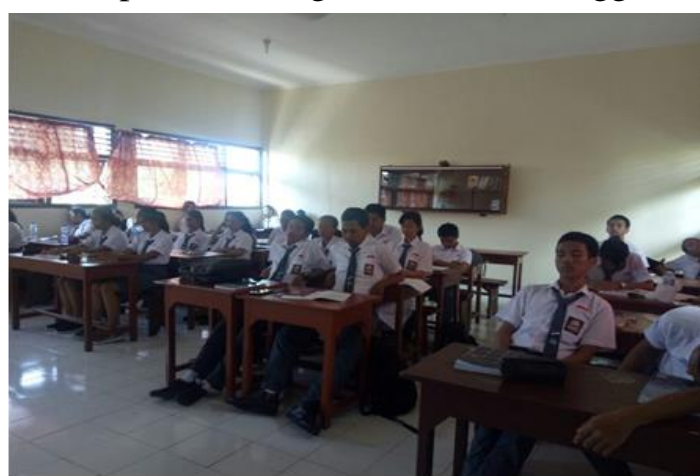

metode Hypnoteaching dan merileksasi para siswa menyimak dengan serius dan fokus.

Gambar 1. Guru menerapkan Hypnoteaching

Pada saat guru merapkan sistem metode Hypnoteaching di kelas dengan seluruh siswa dan siswa mengikuti ucapan satu persatu yang di ajukan oleh guru begitupun dengan siswa jika ada 
yang belum dimengerti siswa brani bertanya langsung kepada guru, sistem metode Hypnoteaching yang di gunakan di SMA Negeri 7 Denpasar adalah dengan memberikan Hypnosis bagi seluruh siswa yang mau melakukan dengan serius yang diberikan oleh guru.

\subsection{Efektivitas penerapan metode Hypnoteaching dalam meningkatkan aktivitas belajar siswa}

Mengajar bagi seseorang guru bukanlah sekedar menyampaikan pengetahuan bagi siswa. Mengajar yang baik adalah mengajar bertujuan, jika tujuannya mengajar yang baik, maka seorang guru haruslah mengetahui sasaran terhadap metode yang tepat untuk diterapkan. Disamping itu, cara yang tepat digunakan dalam menerapkan metode mengajar yang baik ialah membuat persiapan sebaik mungkin sesuai presedur dalam mengajar, membuat siswa agar tetap aktif, memberikan tugas kepada siswa sesuai dengan kemampuan, minat dan kebutuhannya serta menciptakan suasana kelas yang bernilai dan berkesan bagi siswa.

sangat tepatlah jika setiap proses belajar mengajar mengacu kepada kenyamanan siswa sendiri karena hal tersebut akan akan memberikan dampak pada suasana kelas yang menjadi lebih menyenangkan. Jika pada saat belajar dengan cara konvensional saja siswa cendrung cepat bosan dan pasif, maka hal sebaliknya dirasakan saat belajar dengan menggunakan metode Hypnoteaching. Siswa sangat antusias dan bersemangat mendengarkan dan menjawab pertanyaan yang diberikan oleh guru. Selain menjawab siswa juga menanyakan kepada guru hal-hal yang kurang dimengerti.

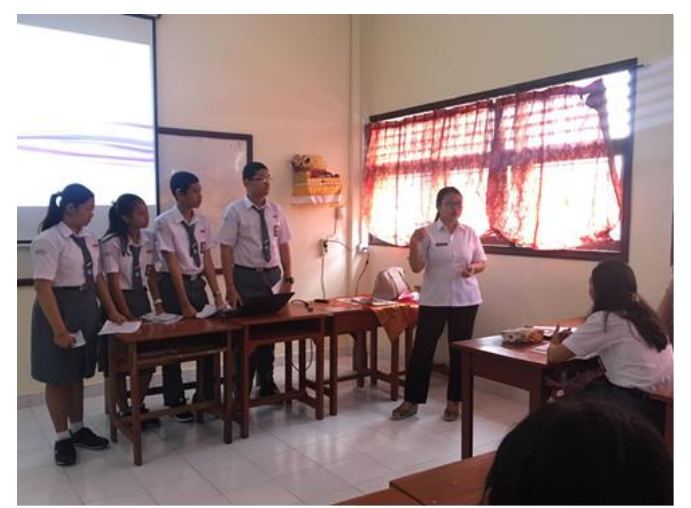

Gambar 2. Siswa aktif bertanya kepada guru

Penerapan metode Hypnoteaching yang diberikan oleh guru dikelas $\mathrm{X}$ sangat efektif, karena menjadikan suasana kelas yang pasif menjadi tenang dan aktif apabila di berikan stimulus. apalagi siswa kelas X suka ribut pada saat guru menjelaskan karena masih terbawa suasana belajar di sekolah menengah pertama dan akibat pemberian metode yang kurang tepat

Suasana pembelajaran di kelas yang menyenangkan inilah yang akan menyebabkan siswa menjadi betah saat belajar di dalam kelas. Menurut (Kasmaja, 2016)suasana belajar yang kondusif dan menyenangkan didukung oleh dua hal yaitu faktor guru dan siswa. Namun guru lebih diberatkan karena dalam hal menciptakan suasana belajar yang nyaman bagi siswa terlebih jika siswa (beberapa siswa) memiliki sifat yang kurang antusias dan semangat mengikuti pelajaran. Guru harus pintar-pintar membangun suasana belajar yang aktif dan hidup saat di kelas.

\subsubsection{Meningkatkan aktivitas belajar siswa}

upaya peningkatan motivasi pada siswa hendaknya perlu diketahui terlebih dahulu mengenai masalah-masalah belajar yang menghambat tercapainya tujuan belajar. Meskipun guru secara sungguh - sungguh telah berupaya merancang dan melaksanakan kegiatan pembelajaran yang baik, namun masalah masalah belajar dijumpai oleh guru. Hal ini merupakan pertanda bahwa belajar adalah kegiatan yang dinamis, sehingga guru perlu secara terus-menerus mencermati perubahanperubahan yang terjadi di kelas.

Setelah diterapkannya metode Hypnoteaching, respon siswa yang baik ini merupakan hasil yang dicapai dalam meningkatkan minat belajar siswa untuk menciptakan sumber daya manusia yang baik. Penerapan metode yang menarik dan bervariasi akan membuat siswa tidak merasa jenuh dan bosan saat belajar di dalam kelas. Selain itu metode Hypnoteaching yang dilakukan setelah melakukan pembukaan didalam kelas sebelum memulai pelajaran yang selanjutnya, juga dapat meningkatkan kembali apa yang telah diajarkan sebelumnya. Hal ini diperkuat dengan hasil nilai ulangan harian dan ulangan semester II yang sangat baik yang merupakan hasil pengajaran yang dilakukan dengan Penerapan metode Hypnoteaching.

Nilai pengetahuan dan nilai keterampilan pada semester II rata-rata para siswa mendapatkan nilai yang sangat baik yakni ratarata mendapatkan nilai 84 bahkan 91 setelah diterapkannya metode Hypnoteaching dalam proses pembelajaran dibandingkan dengan nilai ujian semester I dimana dalam proses pembelajarannya masih menggunakan metode konvensional saja yang kebanyakan para siswa mendapatkan nilai tujuh (75 - 82). Ini menunjukan bahwa penggunakan metode Hypnoteaching yang dilakukan membuat siswa 
dapat lebih mudah menerima pengajaran dengan baik dan mampu memahami apa yang diajarkan oleh guru dengan menggunakan metode Hypnoteaching dibandingkan dengan menggunakan metode konvensional. Maka penerapan metode ini dikatakan sangat efektif dalam meningkatan aktivitas belajar siswa.

\subsubsection{Hasil belajar siswa dengan menggunakan metode Hypnoteaching}

Kemajuan aktivitas belajar siswa dapat dilihat dari peningkatan nilai belajar siswa. Untuk mengetahui apakah efektivitas penerapan metode Hypnoteaching dapat meningkatkan aktivitas belajar siswa peneliti akan menghitung nilai rata - rata siswa agar mengetahui efektivitas metode Hypnoteaching dalam meningkatkan aktivitas belajar siswa di kelas X SMA Negeri 7 Denpasar.

1. Menghitung rata - rata nilai siswa kelas $X$ MIPA 6 SMA Negeri 7 Denpasar dengan rumus diatas no 1 . :

$$
\begin{aligned}
& \mathrm{Me}=\frac{\mathbf{2 8 9 5}}{\mathbf{3 3}} \\
& \mathrm{Me}=87,7
\end{aligned}
$$

Jadi, nilai rata- rata siswa. $\mathrm{Me}=88$

Untuk rata - rata (mean) dalam penelitian Efektivitas Penerapan Metode Hypnoteaching dalam meningkatkan aktivitas belajar masuk ke tabel 2.1 Konversi penerapan metode Hypnoteaching kategori "Sangat efektif" dengan dengan nilai rata - rata 88 .

2. Menghitung daya serap (DS) dengan rumus sebagai berikut:

$$
\begin{aligned}
& \text { Ds }=\frac{88}{10} \times 100 \% \\
& \text { Ds }=88 \%
\end{aligned}
$$

Jadi, nilai daya serap siswa. Ds $=88 \%$

Untuk mengetahui efektivitas penerapan metode Hypnoteaching dalam pembelajaran, pedoman konversi yang digunakan adalah pedoman konversi yang sudah di buat pada tabel 2.1 dalam tehnik pengolahan data.

Kreteria yang digunakan untuk menyatakan tingkat keefektifan dalam pembelajaran ini adalah pada kategori efektif dan sangat efektif atau pada katagori efektif keatas.

Dari hasil perhitungan nilai rata-rata dan daya serap siswa diatas diperoleh hasil untuk rata-rata dari keseluruhan hasil belajar siswa di kelas X Mipa 6 SMA N 7 Denpasar adalah 88 dan daya serap dan daya serap diperoleh dilihat dari skor rata-rata siswa adalah $88 \%$. Dari hasil tersebut menunjukan bahwa dilihat dari tabel 2.1 konversi efektivitas metode Hypnoteaching dalam meningkatkan aktivitas belajar siswa menunjukan rata-rata skor atau nilai siswa berada pada rentang 61-100 dengan kategori Efektif dan Sangat efektif.

Jadi dari data perhitungan hasil belajar di atas dilihat bahwa metode Hypnoteaching sangat efektif digunakan dalam meningkatkan aktivitas belajar siswa.

Berdasarkan angket yang telah disebarkan kepada siswa di kelas X Mipa 6 yang berjumlah 33 orang. Data ini digunakan sebagai melihat sejauh mana keefektifan metode Hypnoteaching di kelas X Mipa 6 SMA Negeri 7 Denpasar dan menggunakan empat konverensi "Sangat Efektif", "Efektif", "Cukup Efektif" dan "Kurang Efektif" setelah dianalisis dan di peroleh hasil data.

Dari hasil penyebaran Angket diatas walaupun ada yang menunjukan bahwa "cukup efektif" tetapi sebagian besar siswa menunjukan hasil yang bagus atau bisa disebutkan dengan "Sangat Efektif" dan dapat di simpulkan sejauhmana efektivitas penerapan metode Hypnoteaching dalam meningkatkan aktivitas belajar siswa "Sangat Efektif" dan terlihat dari hasil angket yang disebar.

\section{KESIMPULAN}

Setelah mengadakan penelitian dan analisis, maka peneliti menarik simpulan berhubung dengan "Efektifitas penerapan metode Hypnoteaching dalam meningkattkan aktivitas belajar siswa" berdasarkan pembahasan hasil dapat disimpulkan sebagai berikut :

Hypnoteaching merupakan alternatif yang bisa digunakan guru dalam membangun suasana pembelajaran yang efektif dan menyenangkan. Metode Hypnoteaching merupakan bagian dari ilmu hypnosis yang bisa embawa siswa pada suasana relaksasi dalam menerima materi pelajaran. Adapun sistem kerja metode Hypnoteaching adalah guru melakukan komunikasi pada alam bawah sadar siswa. Dengan cara merubah gelombang otak dari beta ke alpha. Hypnosis dalam pembelajaran bukanlah model hypnosis yang dipersepsikan dalam acara televisi. hypnosis dalam pembelajaran hanya berusaha membangun kondisi yang kondusif dan menyenangkan dalam proses pembelajaran (siswa tidak dibuat tertidur). Dalam kondisi alpha konsentrasi siswa akan terfokus saat inilah proses pembelajaran akan menjadi lebih bermakna.

Keefektifan ditunjukan dari hasil ujian semester II di kelas X SMA N 7 Denpasar 
diperoleh nilai rata - rata dari jumlah nilai seluruh siswa adalah 88 dan dari rata - rata tersebut diketahui bahwa daya serap dari siswa adalah $88 \%$. Dari hasil perhitungan tersebut menunjukan bahwa nilai rata - rata siswa dalam konversi efektivitas belajar siswa terletak pada rentang 86 - 100 dengan kategori "Sangat Efektif'. Jadi dari data perhitungan hasil belajar diatas dapat di lihat bahwa metode Hypnoteaching efektif digunakan dalam meningkatkan aktivitas belajar siswa.

\section{DAFTAR PUSTAKA}

Arta Wiguna, I. B. A. (2017). Penerapan Metode Hypnoteaching Dalam Meningkatkan Aktivitas Belajar Siswa. Intitut Hindu Dharma Negeri Denpasar.

Hasbullah, H., \& Rahmawati, E. Y. (2015). Pengaruh Penerapan Metode Hypnoteaching terhadap Motivasi Belajar Mahasiswa Universitas Indraprasta PGRI. Formatif: Jurnal Ilmiah Pendidikan MIPA. https://doi.org/10.30998/formatif.v5i1.163

Karim, A. (2017). Efektivitas Partisipasi Perempuan Pada Pendidikan Non Formal di Pusat Kegiatan Belajar Masyarakat (PKBM) Kecamatan Wedarijaksa Kabupaten Pati. INFERENSI, 119-138. https://doi.org/10.18326/infsl3.v11i1.119140

Kasmaja

H. (2016).

EFEKTIVITAS

IMPLEMENTASI

METODE

HYPNOTEACHING UNTUK

MENINGKATKAN MOTIVASI DAN HASIL BELAJAR MATEMATIKA PADA SISWA SMP NEGERI. Journal of Educational Science and Technology (EST).

https://doi.org/10.26858/est.v2i1.1889

Kihlstrom, J. F. (2016). Hypnosis. In Encyclopedia of Mental Health: Second Edition. https://doi.org/10.1016/B978-012-397045-9.00180-4

Sudarsana, I. K. (2017). Membentuk Karakter Anak sebagai Generasi Penerus Bangsa Melalui Pendidikan Anak Usia Dini. Jurnal Purwadita.

Sugiyono. (2012). Metode Penelitian Kuantitatif, Kualitatif dan R \& D.Bandung:Alfabeta. Metode Penelitian Kuantitatif, Kualitatif Dan $R \quad \& \quad$ D.Bandung:Alfabeta. https://doi.org/10.1017/CBO97811074153 24.004

Sugiyono, P. D. (2014). Populasi dan sampel. Metode Penelitian Kuantitatif, Kualitatif Dan $R \& D$.

Yustisia. (2016). Seni ajar mengeksplorasi otak siswa dengan Hypnoteaching. Ar-ruzz Media.

Arta Wiguna, I. B. A. (2017). Penerapan Metode Hypnoteaching Dalam Meningkatkan Aktivitas Belajar Siswa. Intitut Hindu Dharma Negeri Denpasar.

Hasbullah, H., \& Rahmawati, E. Y. (2015). Pengaruh Penerapan Metode Hypnoteaching terhadap Motivasi Belajar Mahasiswa Universitas Indraprasta PGRI. Formatif: Jurnal Ilmiah Pendidikan MIPA. https://doi.org/10.30998/formatif.v5i1.163

Karim, A. (2017). Efektivitas Partisipasi Perempuan Pada Pendidikan Non Formal di Pusat Kegiatan Belajar Masyarakat (PKBM) Kecamatan Wedarijaksa Kabupaten Pati. INFERENSI, 119-138. https://doi.org/10.18326/infsl3.v11i1.119140

Kasmaja, H. (2016). EFEKTIVITAS IMPLEMENTASI METODE HYPNOTEACHING UNTUK MENINGKATKAN MOTIVASI DAN HASIL BELAJAR MATEMATIKA PADA SISWA SMP NEGERI. Journal of Educational Science and Technology (EST).

https://doi.org/10.26858/est.v2i1.1889

Kihlstrom, J. F. (2016). Hypnosis. In Encyclopedia of Mental Health: Second Edition. https://doi.org/10.1016/B978-012-397045-9.00180-4

Sudarsana, I. K. (2017). Membentuk Karakter Anak sebagai Generasi Penerus Bangsa Melalui Pendidikan Anak Usia Dini. Jurnal Purwadita.

Sugiyono. (2012). Metode Penelitian Kuantitatif, Kualitatif dan R \& D.Bandung:Alfabeta. Metode Penelitian Kuantitatif, Kualitatif Dan $R \quad \& \quad$ D.Bandung:Alfabeta. https://doi.org/10.1017/CBO97811074153 24.004

Sugiyono, P. D. (2014). Populasi dan sampel. Metode Penelitian Kuantitatif, Kualitatif Dan $R \& D$.

Yustisia. (2016). Seni ajar mengeksplorasi otak siswa dengan Hypnoteaching. Ar-ruzz Media. 